\title{
Poor Lives Matter: COVID-19 and the Plight of Vulnerable Groups with Specific Reference to Poverty and Inequality in South Africa
}

\author{
John C Mubangizi* \\ University of the Free State, Bloemfontein, South Africa \\ MubangiziJC@ufs.ac.za
}

\begin{abstract}
This article explores the impact of the COVID-19 pandemic on vulnerable people in South Africa in the specific context of poverty and inequality. It does so by first looking at the conceptual context and then highlighting the extent of the impact both from a constitutional and human rights context and from a legislative context. It uses the poor and vulnerable as a proxy to explore the impact of the pandemic (and the measures put in place to contain it) on the specific constitutional rights of vulnerable people, before suggesting a human rights-based approach to managing the pandemic. It concludes that, despite the South African government having undertaken some of the actions recommended, there remains room for improvement and scope for further research, as the pandemic is expected to continue for some time.
\end{abstract}

\section{Keywords}

COVID-19, vulnerable groups, poverty, inequality, human rights, constitution, legislation

\section{INTRODUCTION}

The disproportionate impact of the novel coronavirus (COVID-19) on poor and vulnerable groups of people worldwide has been widely acknowledged. Much has also been written on how COVID-19 has exposed stark social and economic inequalities, with the poor and marginalized communities bearing much of the brunt of the crisis. It is these same marginalized groups that are usually vulnerable to disasters such as famine and hunger, wars, civil instability, epidemics and pandemics.

The dynamics of the disproportionate impact of the COVID-19 pandemic on vulnerable groups tend to vary from society to society. In the USA, such disproportionate impact has been associated with racial and ethnic minorities. These are the very same populations who were more likely to be poor before the

LLB (Makerere University), LLM in public law (University of Cape Town), LLD (University of Durban-Westville (now University of KwaZulu-Natal). Professor and dean, Faculty of Law, University of the Free State, South Africa. 
economic crisis caused by COVID-19. Similarly, evidence has emerged in the United Kingdom that the pandemic has disproportionately affected people from black, Asian, and minority ethnic (BAME) communities. Data released as early as April 2020 showed that "of 6,574 patients with COVID-19 in intensive care, one third were from non-white ethnic groups [in a country where] ethnic minorities make up only $13 \%$ of the population as a whole". ${ }^{1}$ This is a global trend. Indeed, according to the UK Office of National Statistics, globally, black people are more than four times more likely to die from COVID-19 than white people. ${ }^{2}$ The dynamics are no different in South Africa. According to one South African commentator, "[b]lack people are more likely to contract COVID-19, less likely to be tested and treated, and more likely to die, if they contract the virus, due mainly to the history of systemic racism". ${ }^{3}$ In South Africa, poor people are generally black and mainly live in rural areas or townships and informal settlements.

The purpose of this article is to explore the impact of the COVID-19 pandemic on vulnerable people in South Africa in the specific context of poverty and inequality. This is done from a legal perspective by focusing on the constitutional and legal framework governing the management of the pandemic and how this relates to the poor. The article then suggests a human rights-based approach aimed at minimizing the disproportionate impact of the pandemic on the poor.

\section{CONCEPTUAL CONTEXT}

\section{COVID-19}

The purpose and scope of this article do not lend themselves to a detailed scientific or medical explanation of COVID-19. Suffice to say that it is an infectious and deadly coronavirus that has infected millions of people and killed hundreds of thousands across the globe. The first confirmed case of COVID-19 in South Africa was reported on 5 March $2020 .{ }^{4}$ By that time, the virus, which had been first reported in China on 31 December 2019,5 was infecting thousands of people in Europe and the USA. It was declared a

1 T Kirby "Evidence mounts on the disproportionate effect of COVID-19 on ethnic minorities” (2020) 8/6 The Lancet: News 547.

2 Office of National Statistics "Coronavirus (COVID-19) related deaths by ethnic group, England and Wales: 2 March 2020 to 10 April 2020", available at: <https://www.ons. gov.uk/peoplepopulationandcommunity/birthsdeathsandmarriages/deaths/articles/coro navirusrelateddeathsbyethnicgroupenglandandwales/2march2020to10april2020> (last accessed 13 July 2021).

3 B Mohale "It's no coincidence that COVID-19 disproportionately infects and kills black people" (4 August 2020) The Daily Maverick, available at: <https://www.dailymaverick.co. za/opinionista/2020-08-04-its-no-coincidence-that-covid-19-disproportionately-infectsand-kills-black-people/> (last accessed 13 July 2021).

4 L Kiewit "Health department confirms South Africa's first COVID-19 case" (5 March 2020) Mail \& Guardian.

5 "Novel coronavirus (2019-nCoV) situation report 1" (21 January 2020, WHO), available at: 
pandemic by the World Health Organization (WHO) on 11 March $2020 .{ }^{6}$ As the virus spread, several countries across the globe put into place various measures to contain it, including lockdowns, states of disaster and/or states of emergency. Both the pandemic and the containment measures have had significant implications for the social, economic and psychological well-being of individuals, communities, nations and regions. As mentioned above, vulnerable groups especially the poor, have been the most negatively impacted.

One of the main characteristics of COVID-19 is its capability for rapid human-to-human transmission resulting in its ability to spread widely and quickly across communities and nations. By mid-August 2020, barely eight months after it was first detected, the virus had spread to 235 countries or territories, infected more than 31 million people and caused more than 970,000 deaths. ${ }^{7}$ At that same time, South Africa had recorded 665,188 positive cases and a death toll of just over $16,200 .^{8}$ These were the highest numbers for any country on the African continent.

\section{Vulnerable groups}

According to the Collins English Dictionary, "vulnerable" is defined as "capable of being physically or emotionally wounded or hurt ... exposed to attack". ${ }^{9}$ By implication, all human beings are therefore vulnerable. This is because "they are all susceptible to harm, to disease, to suffering, to be abused or exploited by others". ${ }^{10}$ According to Dhai, "[h]uman vulnerability is intrinsically connected to the essential notion of personal integrity and could be perceived as an inescapable dimension of human life and an integral component in the shaping of human relationships. Human vulnerability acknowledges that at some point, all human beings may lack the ability to protect themselves from harms which at times may even be inflicted by other human beings". ${ }^{11}$

Because vulnerability is relative and because levels of vulnerability may have a homogeneous nature, it is possible to identify groups of people that are

contd

<https://www.who.int/docs/default-source/coronaviruse/situation-reports/20200121-s itrep-1-2019-ncov.pdf?sfvrsn=20a99c10_4> (last accessed 9 August 2021).

6 "WHO director-general's opening remarks at the media briefing on COVID-19: 11 March 2020", available at: <https://www.who.int/dg/speeches/detail/who-director-general-s-o pening-remarks-at-the-media-briefing-on-covid-19-11-march-2020> (last accessed 22 July 2021).

7 WHO "Coronavirus disease (COVID-19) pandemic" (data as at 24 September 2020), available at <https://www.who.int/emergencies/diseases/novel-coronavirus-2019> (as accessed on 24 September 2020).

8 COVID-19 Coronavirus South African Resource Portal, available at <https://sacoronavirus. co.za/> (last accessed 13 July 2021).

$9 \quad$ Collins English Dictionary (6th ed, 2006, Collins) at 1827.

10 A Dhai "Vulnerability exploited and a population betrayed" (2012) 5/2 The South African Journal of Bioethics and Law 62 at 62. Ibid. 
more particularly vulnerable than others, hence the concept of "vulnerable groups". In human rights parlance, this refers to groups of people who "require special attention to ensure that they enjoy their human rights, because their perspectives are not automatically included in the actions and thoughts of dominant groups". ${ }^{12}$ These are "people whose rights are most at risk of being violated". ${ }^{13}$ That is why, in human rights rhetoric, vulnerability is usually portrayed in collective terms, namely, vulnerable groups whose rights should enjoy special protection as they "are perceived to be at a particular risk of being violated". ${ }^{14}$ Furthermore, in human rights discourse, "the term vulnerability is used to indicate a heightened susceptibility of certain individuals or groups to being harmed or wronged by others or by the state". ${ }^{15}$ A perusal of relevant literature identifies several internationally recognized vulnerable groups. These include people with limited resources (the poor), people with increased relative risk of morbidity, mother-child mortality, women-headed households, children with special needs, elderly persons, youth, ethnic minorities, displaced populations, people who live away from services, persons suffering from chronic illnesses and disabled persons. This, obviously, is not an exclusive list.

In the context of poverty, vulnerability has to be understood not only in terms of the exposure to poverty alone, but also in terms of the inability to cope with the risks of being poor. This is because not all poor people are vulnerable in the same ways and may, therefore, have different livelihood and coping strategies. According to Coetzee, "poverty and vulnerability do not coincide in the same way in all cases, ... amongst the poor, there may be varying levels and patterns of vulnerability - depending on the multitude of dynamic processes through which individuals and households respond to changes in the environment, adopt and adjust strategies, and reconfigure their relative well-being". ${ }^{16}$

\section{Poverty}

Poverty is one of those things that should hardly need defining: you know it when you see it. That is why the World Bank has described poverty as follows: "[p]overty is hunger. Poverty is lack of shelter. Poverty is being sick and not being able to see a doctor. Poverty is not having access to school and not

12 A Timmer, B Majtényi, K Häusler and O Salát "EU Human rights, democracy and rule of law: From concepts to practice" (31 December 2014, European Commission), available at: <http://www.fp7-frame.eu/wp-content/uploads/2016/08/10-Deliverable-3.2.pdf> (last accessed 13 July 2021).

13 Ibid.

14 Ibid.

15 A Andorno "Is vulnerability the foundation of human rights?" in A Masferrer and E García-Sánchez (eds) Human Dignity of the Vulnerable in the Age of Rights (2016, Springer International Publishing) 257 at 258.

16 E Coetzee "Urban vulnerability: A conceptual framework" in C Nomdo and E Coetzee (eds) Urban Vulnerability: Perspectives from Southern Africa (2002, Periperi) 2 at 5. 
knowing how to read. Poverty is not having a job, is fear for the future, living one day at a time". ${ }^{17}$

Despite this seemingly straightforward and simple description, the debate over poverty definitions is never-ending, resulting in the concept being defined in various and sometimes disparate ways. Definitions vary from the simplistic to the more sophisticated. The New Encyclopaedia Britannica, for example, defines poverty as "the state of one who lacks the usual or socially acceptable amount of money or material possessions". ${ }^{18} \mathrm{~A}$ more detailed definition is offered by the UN, which defines poverty as:

“... the total absence of opportunities, accompanied by high levels of undernourishment, hunger, illiteracy, lack of education, physical and mental ailments, emotional and social instability, unhappiness, sorrow and hopelessness for the future. It is also characterized by a chronic shortage of economic, social and political participation, relegating individuals to exclusion as social beings, preventing access to the benefits of economic and social development and thereby limiting their cultural development" ${ }^{19}$

Some have described poverty from a gendered perspective. Placing poverty in a typical African context, Obiageli Ezekwesili once described it as follows: "[t]he face of poverty [in Africa] is female... She is 18.5 years old. She lives in a rural area. She has dropped out of school. She is single, but is about to be married or be given in marriage to a man approximately twice her age. She will be the mother of six or seven kids in another 20 years". ${ }^{20}$

The UN Committee on Economic, Social and Cultural Rights has provided a more comprehensive and rights-sensitive definition of poverty. The committee defined it as "a human condition characterized by the sustained or chronic deprivation of the resources, capabilities, choices, security and power necessary for the enjoyment of an adequate standard of living and other civil, cultural, economic, political and social rights". ${ }^{21}$ The former UN special

17 World Bank as quoted in M Sanal and L Zare "End poverty with true management" (2015) 6/9 International Journal of Business and Social Science 98 at 98.

18 New Encyclopaedia Britannica (1993, Encyclopaedia Britannica) at 652.

19 R Blanco "How we define poverty: Eradicating extreme poverty and hunger" (1 December 2002) UN Chronicle.

20 Obiageli Ezekwesili, World Bank vice president for the Africa region, addressing the conference on Women and the Changing Global Outlook (Washington DC, USA, 8 May 2009): "In Africa, 'poverty has a female face” (15 May 2009) Reliefweb, available at: <https://reliefweb.int/report/ethiopia/africa-poverty-has-female-face> (last accessed 9 August 2021).

21 "Substantive issues arising in the implementation of the International Covenant on Economic, Social and Cultural Rights: Poverty and the International Covenant on Economic, Social and Cultural Rights" (statement adopted by the Committee on Economic, Social and Cultural Rights, 4 May 2001), UN doc E/C.12/2001/10, available at: <www.unhchr.ch/tbs/doc.nsf/\%28Symbol\%29/E.C.12.2001.10.En> (last accessed 13 July 2021). 
rapporteur on extreme poverty and human rights, however, proposed a nuanced and more realistic definition of poverty. According to the report of the special rapporteur, "poverty is a political choice and its elimination requires reconceiving the relationship between growth and poverty elimination; tackling inequality and embracing redistribution; ... implementing universal social protection; centering the role of government [and] embracing participatory governance", ${ }^{22}$ among other things. The report goes on to say that "extreme poverty is and must be understood as a violation of human rights". ${ }^{23}$

Poverty is a major defining feature of the majority of the South African population. According to a 2017 report of Statistics South Africa (Stats SA) on poverty trends, 66.6 per cent (31.6 million individuals) of the South African population were living in poverty in 2006. ${ }^{24}$ This decreased to 53.2 per cent ( 27.3 million) in 2011 , but increased to 55.5 per cent (30.4 million) in 2015; the number living in extreme poverty in 2015 was 13.8 million. ${ }^{25}$ Although the impact of poverty in South Africa is not very different from its impact in other societies, it tends to take on a different dimension due to the country's history, which is characterized by discrimination and oppression based on race. In that regard, a 2019 government report on poverty and inequality stated that, "while poverty is not confined to any one racial group in South Africa, it is concentrated among blacks, particularly Africans". ${ }^{26}$

\section{Inequality}

Unlike poverty, inequality is a simpler concept to define. It simply means "the state of not being equal, especially in status, rights, and opportunities". ${ }^{27}$ In other words, it refers to the condition of being unequal in respect of opportunity, treatment or status. ${ }^{28}$ That said however, like poverty, inequality is a concept that tends to lend itself to some confusion as it sometimes means

22 "The parlous state of poverty eradication" (7 July 2020, report issued by P Alston, special rapporteur on extreme poverty and human rights, presented to the UN Human Rights Council), UN doc A/HRC/44/40, available at: <https://www.ohchr.org/EN/Issues/Po verty/Pages/parlous.aspx> (last accessed 13 July 2021). Ibid.

24 Poverty Trends in South Africa: An Examination of Absolute Poverty Between 2006 and 2015 (2017, Stats SA), available at: <http://www.statssa.gov.za/publications/Report-03-1006/Report-03-10-062015.pdf> (last accessed 13 July 2021).

25 Ibid.

26 "Poverty and inequality in South Africa: Final report 2019" (South African government), available at: <https:/www.gov.za/documents/poverty-and-inequality-south-africa-finalreport> (last accessed 13 July 2021).

27 Adapted from A Hornby (ed) Oxford Advanced Learner's Dictionary (10th ed, 2020, Oxford University Press) at 435.

28 See JC Mubangizi "Protecting human rights amidst poverty and inequality: The South African post-apartheid experience on the right of access to housing" (2008) 2 African Journal of Legal Studies 131. 
different things to different people. This usually happens when people fail to distinguish between economic inequality or income inequality and the broader inequality in living conditions or standards of living. For the purposes of the discussion in this article, the latter conceptualization is preferred. In that regard, inequality is different from poverty, but quite closely related to it. Inequality concerns disparities in living standards across a whole community, whereas poverty focuses on those whose standard of living falls below a particular threshold. ${ }^{29}$

With a Gini coefficient of 0.63 , South Africa has the dubious honour of being the most unequal society in the world. ${ }^{30}$ According to a 2019 Stats SA report, "in addition to being extremely high, South African inequality appears to be remarkably persistent". ${ }^{31}$ The report also states that "the Gini coefficient for black Africans was the highest ... compared to the other three population groups, while whites had the lowest Gini coefficient". ${ }^{32}$

The link between COVID-19, poverty and inequality among the poor and marginalized groups in South Africa was highlighted in a recent UN study. ${ }^{33}$ Focusing on how COVID-19 drives temporary and long-term changes in poverty levels in South Africa, the study found, inter alia, that poorer households have been more negatively affected by the pandemic. It also found that the number of people living in poverty and extreme poverty increased due to the pandemic, as did inequality. According to the study: "[i]ncome inequality increases due to the pandemic, exacerbating the already high-income disparities in South Africa, and compromising South Africa's progress towards attaining targets under the Sustainable Development Goals particularly regarding poverty, health, education, employment and inequalities". 34

The obvious relationship between inequality and poverty is quite important, particularly in the context of this discussion. From the discussion so far, it is easy to adduce that, if inequality is high in a particular community, the poverty rate will also be high and, if inequality rises, so does poverty. It is against that conceptual background that this article explores a legal perspective of the impact of COVID-19 on the poor in South Africa, an aspect to which this article now turns.

29 A McKay "Defining and measuring inequality" 20021 Inequality Briefing 1.

30 "The World Bank in South Africa: Overview", available at: < https://www.worldbank. org/en/country/southafrica/overview\#: :text=South\%20Africa\%20remains\%20a\%20dual, does\%20not\%20generate\%20sufficient\%20jobs> (last accessed 9 August 2021).

31 R Maluleke Inequality Trends in South Africa: A Multidimensional Diagnostic of Inequality (2019, Stats SA), available at: <http://www.statssa.gov.za/publications/Report-03-1019/Report-03-10-192017.pdf> (accessed 13 July 2021).

32 Ibid.

33 See COVID-19 In South Africa: Socio-Economic Impact Assessment (2020, UN Development Programme), available at: <https://www.za.undp.org/content/south_africa/en/home/1 ibrary/socio-economic-impact-of-covid-19-on-south-africa/> (last accessed 13 July 2021). Id at 20 . 


\section{THE IMPACT OF COVID-19 ON THE POOR IN SOUTH AFRICA: A LEGAL PERSPECTIVE}

\section{The constitutional and human rights context}

Mention was made above of the various measures put in place by several countries across the globe to contain the spread of the COVID-19 virus. In South Africa, the government declared a state of disaster on 15 March 2020, followed a few days later by a lockdown that was later applied in five alert levels in line with a risk-adjusted strategy. Both the state of disaster and lockdown were implemented through urgent and drastic measures contained in stringent regulations aimed at limiting the spread of the virus and managing the disease. It is important to point out that the impact of COVID-19 on the poor and vulnerable is therefore not limited to the virus alone but also includes the effects and implications of the lockdown and other measures aimed at limiting the spread of the virus.

Although the words "poor" or "poverty" are not mentioned anywhere in the South African Constitution, 1996 (the Constitution), there are a number of constitutional provisions that are relevant to poverty. To begin with, the preamble signals the role of the Constitution in addressing poverty by setting out four objectives, one of which is to "improve the quality of life of all citizens and free the potential of each person". The opening section also signals the intention of the Constitution to "establish a society based on democratic values, social justice and fundamental human rights". ${ }^{35}$ In the specific context of COVID-19 and vulnerability due to poverty and inequality, the role of the Constitution mainly centres on the constitutional protection of the relevant rights contained in the Bill of Rights, ${ }^{36}$ which is described as "a cornerstone of democracy ... [that] affirms the democratic values of human dignity, equality and freedom". ${ }^{37}$

Foremost among those rights is the right to equality. ${ }^{38}$ Section 9(1) of the Constitution provides that "everyone is equal before the law and has the right to equal protection and benefit of the law". This constitutional guarantee notwithstanding, the pandemic has deepened pre-existing inequalities, as mentioned above, and the poor and vulnerable have particularly come under pressure. COVID-19 has directly and indirectly magnified these pre-existing inequalities, which manifest themselves through lack of access to income, employment, assets, healthcare, education, equal opportunity and public services. As a result, during lockdown, the poor were disproportionately affected by the lack of essential goods and services, including food, water and healthcare. Another dimension to this is that, because of the patriarchal nature of South Africa's traditional communities, when there is limited access to

\footnotetext{
35 Constitution, sec 1(a).

36 Id, chap 2.

37 Id, sec 7(1).

38 Id, sec 9.
} 
resources within the home or the community, gender inequality may mean women and girls have even less access. Indeed, women and girls in poor communities have been impacted more by COVID-19 than their male counterparts, with reports of gender-based violence increasing during lockdown.

Section 36 of the Constitution allows for certain rights to be limited, provided such limitation is reasonable and justifiable in an open and democratic society. Among the civil rights that were limited under lockdown are the rights to human dignity, ${ }^{39}$ privacy, ${ }^{40}$ freedom and security of the person, ${ }^{41}$ freedom of association, ${ }^{42}$ freedom of movement ${ }^{43}$ and trade. ${ }^{44}$ Due to various reasons related to their living conditions, there is no doubt that the poor were more affected by the limitation of these rights. For example, it is reported that, after announcing the lockdown, "[police] officers in Johannesburg were seen indiscriminately using water cannons on civilians and firing rubber bullets in the city's poorest neighbourhoods". 45

The right of access to information ${ }^{46}$ is another constitutional right that has significant implications for poor, vulnerable people as a result of COVID-19 and related lockdown measures. As noted by one commentator, "accessing timely and relevant information such as public health guidelines and education on the COVID-19 pandemic is critical in enhancing people's knowledge about the preventive measures and what the government expects from the public". ${ }^{47}$ This information is communicated through various channels including the internet, print media, radio and television broadcasts. All of these have cost implications. Many poor people, particularly those living in rural communities, are unable to access COVID-19-related information from government and health agencies because of the costs involved. This is compounded by other factors, such as lack of access to electricity and poor mobile and internet connectivity.

The Constitution is hailed as one of the most progressive constitutions in the world. ${ }^{48}$ This is mainly because it contains a Bill of Rights that incorporates all categories of human rights that are ordinarily recognized by the main

39 Id, sec 10.

40 Id, sec 14.

41 Id, sec 12.

42 Id, sec 18.

43 Id, sec 21.

$44 \mathrm{Id}$, sec 22.

45 PJ Heijmans, B Pradhan and P Bax "Locked in cages, beaten and shamed: Virus laws lead to abuses" (2 April 2020) Bloomberg, available at: <https://www.bloomberg.com/news /articles /2020-04-02/locked-in-cages-beaten-and-shamed-virus-laws-lead-to-abuses> (last accessed 13 July 2021).

46 Constitution, sec 32.

47 H Dube "COVID-19 and the access to information conundrum in Africa" AfricLaw (10 April 2020), available at: <https://africlaw.com/2020/04/10/covid-19-and-the-access-toinformation-conundrum-in-africa/> (last accessed 13 July 2021).

48 See H Melber "Constitutionalism in democratic South Africa: Celebrations, contestations and challenges” (2014) 36/2 Strategic Review for Southern Africa 210. 
international human rights instruments. These include civil and political rights, socio-economic rights and the so-called third-generation rights. Of all these categories of human rights, it is mainly through the protection (or lack thereof) of socio-economic rights that COVID-19 impacts the poor. This is because these rights directly affect the poor. This, in turn, is because they "have important social and economic ramifications as most of them reflect specific areas of basic needs or delivery of particular goods and services". 49

Included among the relevant socio-economic rights are: property rights, ${ }^{50}$ and rights relating to housing, ${ }^{51}$ healthcare, food, water and social security, ${ }^{52}$ and education..$^{53}$ In so far as housing is concerned, it is important to note that about 13.6 per cent of the South African population (about 7 million people) live in informal settlements. ${ }^{54}$ Most of these settlements have no clean running water, electricity or basic sanitation. The implications with respect to COVID-19 cannot be overemphasized. In July 2020 for example, the highest prevalence of COVID-19 in the city of Cape Town was found in Khayelitsha and Klipfontein, the two districts with the highest concentrations of informal housing. ${ }^{55}$ The main reason for this is that residents of these informal settlements are generally poor and lack adequate water supplies and sanitation. As a result, it is difficult for them to practise social distancing or good hygiene practices in the overcrowded conditions. Indeed, the so-called non-pharmaceutical measures of physical distancing, washing hands with soap and water, and self-isolation, require access to essential services, such as adequate clean water.

Section 27 of the Constitution provides for the right of access to healthcare services, sufficient food and water and social security. This is a critical provision relating to health generally and COVID-19 specifically, in the context of poverty and inequality. Poor health perpetuates poverty and poverty exacerbates poor health. The same applies to food. Poor people are unable to access sufficient nutritious food. This affects their health. Social security is no different either. The need to protect the right to social security is particularly critical in South Africa due to the high levels of poverty and unemployment, among other things. Social grants were already insufficient before COVID-19; now they are overstretched. ${ }^{56}$ The result is that the poor are more susceptible to the spread of the virus.

49 Mubangizi "Protecting human rights", above at note 28 at 137-38.

50 Constitution, sec 25.

51 Id, sec 26

52 Id, sec 27.

$53 \mathrm{Id}$, sec 30.

54 "General household survey, 2018" (Stats SA), available at: <http://www.statssa.gov.za/?p= 12180> (last accessed 13 July 2021).

55 W Smit "Tackling COVID-19 in informal settlements in Cape Town" (8 July 2020) Thomson Reuters Foundation News, available at: <https://news.trust.org/item/202007081049263gwm4/> (last accessed 13 July 2021).

56 See T Molelekwa "South African social grants are not enough" (29 May 2018) Health eNews, available at: <https://health-e.org.za/2018/05/29/south-african-social-grants-are-not-eno ugh/> (last accessed 13 July 2021). 
Section 29 of the Constitution provides for the right to education, including basic education and further education. This right has to be seen in the context of South Africa's school system being one of the most unequal in the world. This inequality has been further exposed by COVID-19. One of the measures introduced to prevent the spread of the virus was the closure of schools and other educational institutions. In that regard, a research study conducted by Human Rights Watch between April and August 2020 showed that, in common with other countries in sub-Saharan Africa, the closure of schools in South Africa "exacerbated previously existing inequalities, and that children who were already most at risk of being excluded from a quality education have been most affected". ${ }^{57}$

The closure of schools also meant the suspension of the National School Nutrition Programme (NSNP), through which the government provides one nutritious meal per day to all learners in primary and secondary schools. Children from poor and vulnerable communities benefit most from this programme. It is important to note that, in the case of Equal Education and Others $v$ Minister of Basic Education and Others, ${ }^{58}$ the Pretoria High Court held that the suspension of the NSNP infringed children's right to basic nutrition. The Department of Basic Education and provincial education departments were ordered to submit plans for the resumption of the NSNP within ten days and thereafter to provide progress reports every 15 days.

It is also important to note that, during lockdown, many educational institutions moved teaching and learning to online platforms and adopted e-learning approaches. These approaches proved to be discriminatory against children and students from poor backgrounds, as many of them did not have access to devices, data, electricity or internet connectivity to make remote learning possible. This had a negative impact on those learners who were already disadvantaged and in vulnerable situations.

In July 2020 a study was conducted by the Dullah Omar Institute of the University of the Western Cape of COVID-19 on the impact on socio-economic rights in selected informal settlements in Cape Town. ${ }^{59}$ The study, which investigated five communities to find out the socio-economic challenges they were facing during the pandemic, found that, "the communities face differing challenges depending on their location and vulnerabilities. Against the backdrop of an already dire situation, the lockdown has made it even harder for members of these communities to enjoy basic needs and amenities such as food, water and sanitation, information, transportation, employment and health". ${ }^{60}$

57 Human Rights Watch "Impact of COVID-19 on children's education in Africa" (26 August 2020), available at: <https://www.hrw.org/news/2020/08/26/impact-covid-19-childrenseducation-africa> (last accessed 13 July 2021).

58 [2020] ZAGPPHC 306.

59 See R Nanima and E Durojaye "The socioeconomic rights impact of COVID-19 in selected informal settlements in Cape Town” (2020, Dullah Omar Institute). 


\section{The legislative context}

As mentioned above, in order to tackle the pandemic, the South African government declared a state of disaster on 15 March 2020. Unlike states of emergency, which are specifically provided for under section 37 of the Constitution, no constitutional provision is made for states of disaster. The power to declare a state of disaster is, therefore, not derived from the Constitution but rather from the Disaster Management Act. ${ }^{61}$ Under this act, a state of disaster can be declared by the minister for cooperative governance and traditional affairs. ${ }^{62}$ The Disaster Management Act is the primary legislation that deals with disaster management in the country, making it the most important piece of legislation in the management of COVID-19. It provides for an integrated and coordinated disaster management approach by focusing on preventing and mitigating the risk and severity of disasters, emergency preparedness, and the rapid and effective response to disasters, among other things. ${ }^{63}$ A state of disaster is supposed to last for three months but can be extended by the minister for cooperative governance and traditional affairs for one additional month at a time.

Under section 27(2) of the act, "if a national state of disaster has been declared ... the Minister may, subject to subsection (3), and after consulting the responsible Cabinet member, make regulations or issue directions or authorize the issue of directions". Such regulations and directions may be in respect of:

“(a) the release of any available resources of the national government ...

(b) the release of personnel of a national organ of state for the rendering of emergency services;

(c) the implementation of all or any of the provisions of a national disaster management plan ...

(d) the evacuation to temporary shelters of all or part of the population ...

(e) the regulation of traffic ...

(f) the regulation of the movement of persons and goods ..."64

Indeed, regulations relating to COVID-19 under the Disaster Management Act were promulgated initially to come into effect on 26 March $2020 .{ }^{65}$ The regulations addressed, inter alia: release of resources; prevention and prohibition of gatherings; refusal of medical examination, prophylaxis, treatment, isolation and quarantine; and places of quarantine and isolation. They also dealt

61 Act 57 of 2002

62 Id, secs 3 and 27.

63 See id, preamble.

64 Id, sec 27(2).

65 Government Notice 318 of 2020. 
with: closure of schools and partial care facilities; limitation on the sale, dispensing or transportation of liquor; emergency procurement procedures; restrictions on the movement of persons and goods; and prohibition of public transport. The regulations also provided for a number of offences and penalties. These regulations were amended and revised at various stages depending on the level of the risk-adjusted strategy referred to above. ${ }^{66}$

Whereas the thrust of the regulations was to put in place measures intended to limit the spread of COVID-19 and to ensure a state of readiness for the health sector to cope with the expected high number of infections, such measures had a significant impact on the population generally, but more especially on the poor. Measures related to the restrictions on movement, for example, impacted the poor especially, because their ability to eke out a living largely depends on movement from one place to another. The same applies to poor people involved in informal trade, as they could not move their goods to sell in local markets or trading centres.

Measures that restricted people's right to work also had a significant impact on vulnerable workers, especially the poor. These include domestic workers who either lost their jobs altogether or were laid off for a period of time. They also include farmworkers who continued to work during lockdown without the necessary personal protective equipment. Unfortunately, domestic and other casual workers who lost their jobs or were laid off were unable to access social security benefits because they are usually not registered by their employers and contributions are often not made on their behalf.

Another effect of the regulations on the poor was the threat to their food security. The restrictions on the movement of persons and goods, on the right to work and on public transport led to food security being threatened in many poor homes. Moreover, these restrictions had a devastating effect on the economy, which was already in recession. Ultimately, the poor, as always, were most impacted by the failing economy. It has been argued that, considering the impact that these regulations were going to have on civil society, and the poor in particular, the lack of public consultation and community engagement in developing the regulations is concerning. ${ }^{67}$ It was, in part, on the basis of this argument that the regulations were challenged and declared unconstitutional and invalid by the High Court in De

66 The levels of the risk-adjusted strategy were as follows. Level 5: drastic measures to contain the spread of the virus to save lives. Level 4: some activity allowed to resume, subject to extreme precautions to limit community transmission and outbreaks (effective 1 May 2020). Level 3: easing of some restrictions, including on work and social activities, to address a high risk of transmission (effective 1 June 2020). Level 2: further easing of restrictions, while maintaining physical distancing and restrictions on some leisure and social activities to prevent a resurgence of the virus (effective 18 August 2020). Level 1: most normal activity to resume, with precautions and health guidelines to be followed at all times.

67 C Staunton, C Swanepoel and M Labuschagne "Between a rock and a hard place: COVID-19 and South Africa's response" (2020) 7/1 Journal of Law and the Biosciences 4. 
Beer and Others $v$ Minister of Cooperative Governance and Traditional Affairs. The court held that, "[t]he regulations promulgated in respect of Alert Levels 4 and 3 in terms of Section 27(2) of the Disaster Management Act by the Minister in a substantial number of instances are not rationally connected to the objectives of slowing the rate of infection or limiting the spread thereof". ${ }^{68}$

It must be pointed out that this decision attracted considerable criticism. Some argued that the question of the validity of the Alert Level 4 Regulations had become moot since the country had already moved to Alert Level 3.69 Others argued that the judge had adopted a "holus bolus" [all at once] shotgun approach that confused rationality with reasonableness. ${ }^{70}$ The court's decision was indeed contrary to the decision in Mohamed and Others $v$ President of the Republic of South Africa and Others, in which the court correctly applied the principle of rationality and held that the declaration of the state of disaster and the lockdown regulations adopted were constitutionally permissible under section 36 of the Constitution. ${ }^{71}$ Although, unsurprisingly, the minister (in De Beer) was later granted leave to appeal and the case was overtaken by the subsequent transition to Alert Level 2, part of the court's reasoning showed that there was some justification in the unhappiness caused by some of the lockdown regulations.

Besides the constitutional right to equality discussed above, mention should be made of the central equality statute in South Africa: the Promotion of Equality and Prevention of Unfair Discrimination Act. ${ }^{72}$ This statute was enacted "to give effect to section 9 of the Constitution ... so as to prevent and prohibit unfair discrimination and harassment; to promote equality and eliminate unfair discrimination". ${ }^{73}$ Although it does not specifically prohibit discrimination against the poor as such, it does prohibit "the provision or continued provision of inferior services to any racial group, compared to those of another racial group". ${ }^{74}$ This is particularly important in the context of COVID-19, considering that most poor people in South Africa belong to one particular racial group and also considering the various types of services

68 [2020] ZAGPPHC 184, para 9.2.

69 See L le Roux "Quo vadis: Are the lockdown regulations irrational and invalid? A critical analysis of the judgment in De Beer and Others $v$ Minister of Cooperative Governance and Traditional Affairs (21542/2020) [2020] ZAGPPHC 184 (2 June 2020) with regard to the constitutional validity of both the declaration of a state of national disaster and the regulations pursuant thereto" (26 June 2020) LexisNexis, available at: <https://www.lexisnexis.co. za/lexis-digest/resources/quo-vadis-de-beer-case> (last accessed 13 July 2021).

70 J Brickhill "Constitutional implications of COVID-19: The striking down of the lockdown regulations" (7 June 2020) Juta Talking Points, available at: <https://juta.co.za/press-room /2020/06/07/constitutional-implications-covid-19-striking-down-lockdown-regulationsissue-14/> (last accessed 13 July 2021).

71 [2020] ZAGPPHC 120; 2 All SA 844 (GP); 2020 (7) BCLR 865 (GP), para 39.

72 Act 4 of 2000.

73 Id, preamble.

74 Id, sec 7(d). 
required to combat the pandemic. The statute also prohibits "the denial of access to opportunities, including access to services or contractual opportunities for rendering services". ${ }^{75}$ This is also crucial, considering the various opportunities that were lost or gained due to COVID-19, particularly the numerous tenders that arose from the need to procure and supply protective personal equipment.

\section{A HUMAN RIGHTS-BASED APPROACH}

\section{The rationale}

It is clear from this discussion that the COVID-19 pandemic in South Africa not only disproportionately affected vulnerable groups such as the poor, but also impacted negatively on their human rights. It is also clear that the legislative framework was insufficient to manage the pandemic and address the plight of vulnerable groups, such as the victims of poverty and inequality. It is for that reason that protection and respect for human rights should be central to the management of the pandemic. Indeed the Office of the UN High Commissioner for Human Rights (OHCHR) has pointed out that, "respect for human rights across the spectrum, including economic and social rights, and civil and political rights, [is] fundamental to the success of the public health response [to the pandemic]". ${ }^{76}$ In the specific context of vulnerable groups, the WHO has also echoed that sentiment by saying that, because "the threat and experience of COVID-19 occurs differently for different groups ... even within these vulnerable groups there are differences that would benefit from a human rights lens". ${ }^{77}$ A discussion on how COVID-19 has impacted and affected the constitutional rights of poor people was undertaken above. This showed that the pandemic and lockdown regulations have led to the limitation of several civil and political rights and affected socio-economic rights. It is for that reason, and because poor lives matter, that a human rights-based approach (HRBA) to managing the pandemic is proposed.

Descriptions of an HRBA vary. The most appropriate description, however, is one that sees it as "a conceptual framework ... that is normatively based on international human rights standards and operationally directed to promoting and protecting human rights". ${ }^{78}$ It is therefore an approach that makes the principles and standards of human rights central to all aspects of whatever is being implemented or managed. In that regard, it is fair to say that the

75 Id, sec 7(e).

76 M Bachelet "COVID-19 and its human rights dimensions" (OHCHR), available at: <https:// www.ohchr.org/EN/NewsEvents/Pages/COVID-19.aspx> (last accessed 13 July 2021).

77 WHO "Addressing human rights as key to the COVID-19 response" (April 2020), available at: <https://www.who.int/publications/i/item/addressing-human-rights-as-key-to-the-co vid-19-response> (last accessed 13 July 2021).

78 "Human rights-based approach" (UN Sustainable Development Group), available at: <https://unsdg.un.org/2030-agenda/universal-values/human-rights-based-approach> (last accessed 13 July 2021). 
definition or description of an HRBA may often be premised in the context of the organization that is adopting it and what it is being adopted for. According to the Scottish Human Rights Commission for example, the HRBA is:

\begin{abstract}
"about empowering people to know and claim their rights and increasing the ability and accountability of individuals and institutions who are responsible for respecting, protecting and fulfilling rights. This means giving people greater opportunities to participate in shaping the decisions that impact on their human rights. It also means increasing the ability of those with responsibility for fulfilling rights to recognize and know how to respect those rights, and make sure they can be held to account". ${ }^{79}$
\end{abstract}

Because of its emphasis on empowerment, accountability and participation in decision-making, this description is obviously relevant and applicable to the impact of COVID-19 on vulnerable people in South Africa, especially the poor. Also relevant and applicable is the view of the UN Population Fund, which posits that, "[t]he human rights-based approach focuses on those who are most marginalized, excluded or discriminated against. This often requires an analysis of gender norms, different forms of discrimination and power imbalances to ensure that interventions reach the most marginalized segments of the population". ${ }^{80}$

Similarly, the European Network of National Human Rights (ENNHRI) has described the HRBA as, "a conceptual framework directed towards promoting and protecting human rights, based on international human rights standards. It puts human rights and corresponding state obligations at the heart of policy and can be used ... as a tool to empower the most vulnerable people to participate in decision-making processes and hold duty-bearers accountable". ${ }^{81}$

These views and descriptions give credence to the argument and rationale for an HRBA to managing the COVID-19 pandemic, particularly in the context of poverty and inequality in South Africa. This is mainly because central to the HRBA is the recognition that inequality and marginalization deny vulnerable people their human rights and keep them in poverty. The COVID-19 pandemic and its ramifications have only compounded and exposed this inequality, marginalization, denial of human rights and poverty.

79 "What is a human rights based approach?" (Scottish Human Rights Commission), available at: <http://careaboutrights.scottishhumanrights.com/whatisahumanrightsbas edapproach.html> (last accessed 13 July 2021).

80 UN Population Fund "The human rights-based approach", available at: <https://www. unfpa.org/human-rights-based-approach> (last accessed 13 July 2021).

81 "Applying a human rights-based approach to poverty reduction and measurement: A guide for national human rights institutions" (October 2019, ENNHRI), available at: <http://ennhri.org/Applying-a-Human-Rights-Based-Approach> (last accessed 13 July 2021). 


\section{The principles}

From the descriptions and definitions of an HRBA quoted or referred to above, it is clear that the approach should be underpinned by certain human rights principles. These are the very same principles that have been identified by various proponents of the HRBA. ENNHRI has, for example, identified five such key human rights principles: accountability and transparency; participation; non-discrimination and equality; empowerment of rights holders; and legality. ${ }^{82}$ It is important to highlight these principles and show how they reinforce the need for an HRBA to manage the COVID-19 pandemic in a way that mitigates its impact on vulnerable groups, especially the poor.

In so far as the principle of accountability is concerned, it is important that the authorities should be held accountable if and when they fail to fulfil their obligations towards people, especially the poor and vulnerable. When human rights breaches occur, there should be sufficient and effective remedies to deal with those breaches and hold the culprits to account. Similarly, the principle of participation requires that everyone should be entitled to participate in decision-making processes that will result in decisions that affect their rights. As mentioned above, the lack of public consultation and community engagement in developing the lockdown regulations in South Africa was a source of serious concern, especially for the poor who were most adversely affected by the regulations.

In the context of vulnerability, inequality and poverty, the principle of equality and non-discrimination is particularly important. All types of discrimination against any persons or communities because of an association with COVID-19 should be prohibited and prevented. The same applies to discrimination on the basis of any vulnerability, such as age, gender, race or socio-economic status. Measures to prevent the spread of COVID-19 should take into account the potential for increased discrimination against vulnerable groups, especially the poor.

Empowerment is another important principle in the context of vulnerability, poverty and inequality. The disproportionate impact of COVID-19 and related restrictions on vulnerable groups should be anticipated, assessed and addressed. To empower these groups, equitable access to healthcare and other resources to address COVID-19 should be made available, including financial and other forms of assistance.

All these principles should, obviously, be reinforced by the principle of legality, which requires that all interventions, guidelines and measures to prevent the spread of COVID-19 should be in line with the legal rights set out in international and domestic law, particularly the Constitution and the Bill of Rights. Most importantly, the underlying human rights principle is that the management and prevention of COVID-19 should be seen as a human rights obligation. This is mainly because it has a significant impact on several 
fundamental rights (as noted above), more especially the rights of vulnerable groups.

It must be pointed out that the principles discussed above are part of a broader set of UN Guiding Principles on Extreme Poverty and Human Rights. ${ }^{83}$ These "global policy guidelines focused specifically on the human rights of people living in poverty [and were] intended for use by governments to ensure that public policies ... reach the poorest members of society, respect and uphold their rights, and take into account the significant social, cultural, economic and structural obstacles to human rights enjoyment faced by persons living in poverty". ${ }^{84}$

\section{Recommended actions}

The COVID-19 pandemic is not the only disease to have ravaged humanity. There have been numerous epidemics and pandemics in recorded history. In the recent century or so, the world has witnessed several epidemics and pandemics, including the so-called Spanish 'flu (1918-20), Asian 'flu (195758), the AIDS epidemic (1981-present day), the H1N1 swine 'flu pandemic (2009-10), the West African Ebola epidemic (2014-16), the Zika epidemic (2015-present day) and, of course, the COVID-19 pandemic (2019-present day). The HRBA actions recommended here, therefore, are not only aimed at addressing the plight of the poor and vulnerable in the COVID-19 pandemic but are also applicable to any pandemics that might occur in the future. The actions also have to be seen in the context of the rationale and principles of an HRBA discussed above and the specific impact that COVID-19 has had on vulnerable groups, especially the poor.

It should also be mentioned that the actions recommended here are consistent with some actions that have been suggested by several organizations as possible responses broadly consistent with an HRBA that governments can take in managing the COVID-19 pandemic. Those organizations include the Ontario Human Rights Commission, the Manitoba Human Rights Commission, the OHCHR, the UN Development Programme (UNDP) and the UN Sustainable Development Group (UNSDG). ${ }^{85}$

83 See "The guiding principles on extreme poverty and human rights" (OHCHR), available at: <https://www.ohchr.org/en/issues/poverty/pages/dgpintroduction.aspx> (last accessed 13 July 2021).

84 "Guiding principles on extreme poverty and human rights" (UNHCR), available at: < https:// www.ohchr.org/documents/publications/ohchr_extremepovertyandhumanrights_en.pdfs (last accessed 9 August 2021).

85 In that regard, see: Ontario Human Rights Commission "Actions consistent with a human rights-based approach to managing the COVID-19 pandemic", available at: <http://www.ohrc.on.ca/en/actions-consistent-human-rights-based-approach-managingcovid-19-pandemic > (last accessed 13 July 2021); Manitoba Human Rights Commission “A human rights based approach to the COVID-19 pandemic: Principles and actions", available at: <http://www.manitobahumanrights.ca/v1/education-resources/resources/pubs /guidelines/covid19principles.pdf> (last accessed 13 July 2021); and OHCHR, UNDP and 
Mention was made above of the impact of COVID-19 on the socio-economic rights of poor and vulnerable people. The first set of actions, therefore, relate to the protection of such rights through the provision of basic goods and delivery of particular services, such as healthcare services linked to the pandemic. It is submitted that services such as testing, tracing and treatment of COVID-19 patients should be provided without discrimination on the basis of social status or any other condition of vulnerability. Every effort should be made to ensure that healthcare resources are made available to vulnerable groups, especially the poor, on an equitable and non-discriminatory basis.

Moreover, measures should be put in place to eliminate any corruption that may occur in the provision of healthcare and other resources to vulnerable groups. Indeed COVID-19 has exposed the rampant greed and corruption that characterizes South African society, with the perpetrators brazenly hijacking resources and measures put in place to deal with the pandemic. Documented examples include the misallocation of funds from a R500 billion (approximately GBP 22 billion) relief package intended for food parcels and increased social grants for the poor and vulnerable. ${ }^{86}$ Others include "suspected deals between government officials and businesses providing medical equipment $\ldots$ and the sale of food aid parcels meant for the poor". ${ }^{87}$ Decisive action should be taken to eradicate these corrupt practices as they negatively impact not only the ability of the poor and vulnerable to cope with the pandemic, but also the protection and enjoyment of their socioeconomic rights.

Related to this are important actions that should be undertaken to protect the rights relating to privacy and access to information. Broadly speaking, all communities, especially the poor and vulnerable, should have adequate and timely access to public health information, particularly information related to COVID-19. Provision of such information, however, should be done in such a way that safeguards patient confidentiality and protects the right to privacy.

Similarly, it is important to ensure that poor communities have access to basic facilities and services, such as clean water, affordable and sufficient food, and other critical household goods such as soap and sanitary products

contd

UNSDG "Checklist for a human rights-based approach to socio-economic country responses to COVID-19", available at: <https://www.ohchr.org/Documents/Events /COVID-19/Checklist_HR-Based_Approach_Socio-Economic_Country_Responses_COVID19.pdf> (last accessed 13 July 2021).

86 Transparency International "In South Africa, COVID-19 has exposed greed and spurred long-needed action against corruption” (4 September 2020) Corruption Watch, available at: <https://www.transparency.org/en/blog/in-south-africa-covid-19-has-exposed-greedand-spurred-long-needed-action-against-corruption> (last accessed 13 July 2021).

87 P Fray "South Africa: The bigger pandemic is corruption" (27 August 2020) Good Governance Africa, available at: <https://gga.org/south-africa-the-bigger-pandemic-is-co rruption/> (last accessed 13 July 2021). 
necessary to ensure a clean and healthy environment. In that regard, it is imperative to mitigate the disproportionate negative impact that lockdown and public health restrictions and directives such as social distancing, selfisolation and quarantining are likely to have on the poor and vulnerable due to their precarious living conditions.

Related to the issue of living conditions is the issue of homelessness. It is estimated that South Africa is home to more than 200,000 homeless people. ${ }^{88}$ This is a vulnerable group that consists of the poorest of the poor. Under an HRBA, measures should be put in place to protect such people during the pandemic, including provision of temporary and emergency shelters that have facilities for frequent hand washing and implementation of physical distancing or isolation.

Social security in South Africa is not only a constitutional right but is also an important instrument for poverty reduction. It is used "to reduce poverty among vulnerable groups who are needy and without the means to support themselves" ${ }^{89}$ In the context of COVID-19 and an HRBA, government should ensure the right to adequate social security by providing financial assistance and support to those who need it. In so doing, the poor and vulnerable communities should be prioritized. Related to social security is the issue of small businesses and informal employment for low-income workers. Measures should be designed to provide financial assistance to mitigate losses and avoid the closure of struggling small businesses and to assist workers in informal jobs and services that may be adversely affected by COVID-19.

Mention was made earlier of the impact of COVID-19 on education in South Africa, particularly in the context of the country's immensely unequal schooling system. From an HRBA perspective, it is imperative that learning options during the pandemic do not aggravate the existing educational inequalities and that options take into account the challenges faced by learners in poor communities. These challenges are not limited to lack of access to the internet and other online resources, but also include lack of sufficient food as a result of the suspension of the NSNP. In that regard, every effort should be made to provide support to all learners during school closures, with a focus on learners from poor and vulnerable communities.

In fairness, it should be mentioned that the South African government undertook some of these recommended actions through its policy response to the COVID-19 pandemic. Part of this was an economic response focusing on measures such as "tax relief, the release of disaster relief funds, emergency procurement, wage support through the Unemployment Insurance Fund and

88 C Rule-Groenewald, F Timol, E Khalema and C Desmond "More than just a roof: Unpacking homelessness" (2015) Human Sciences Research Council Review, available at: <http://www.hsrc.ac.za/en/review/hsrc-review-march-2015/unpacking-homelessness> (last accessed 13 July 2021).

89 E Kaseke "The role of social security in South Africa" (2010) 53/2 International Social Work 159 at 163. 
funding to small businesses". ${ }^{90}$ The response also included the announcement of a social and economic support package of R500 billion (approximately 10 per cent of GDP) focusing on "redirecting resources to fund the health response to coronavirus ..., providing direct support to households and individuals for the relief of hunger and social distress ..., providing assistance to companies in distress and seeking to protect jobs by supporting workers' wages". ${ }^{91}$ The government was lauded for providing social and economic relief measures to mitigate the impact of the pandemic and the lockdown. In the specific context of the poor and vulnerable, the government was commended for increasing social grants and providing food vouchers and packages, mainly to poor households. ${ }^{92}$ It is worth mentioning that the WHO praised South Africa for "a very prudent, caring approach to the vulnerable population" 93 in its handling of the COVID-19 pandemic.

\section{CONCLUSION}

Poverty and inequality are two defining features of the majority of South African people. These people belong to a group that is broadly defined as poor and vulnerable. Due to their vulnerability, the significant impact that the COVID-19 pandemic has had on them was not unexpected. This article has highlighted the extent of that impact both from a constitutional and human rights context and also from a legislative context. Using poverty and inequality as a proxy, the article has explored the impact the pandemic and the measures put in place to contain it have had on the specific constitutional rights of vulnerable people. It has also discussed the impact of the Disaster Management Act and the regulations made under it. It has been seen that this legislative framework was not only insufficient in addressing the plight of vulnerable groups, but also led to the limitation of a number of their civil and political rights and impacted negatively on their socio-economic rights. Because poor lives matter, the article suggested an HRBA to managing the pandemic.

The article highlighted the rationale for and centrality of an HRBA in managing the pandemic while addressing the plight of vulnerable groups, as echoed by the OHCHR and WHO. It discussed the principles of an HRBA and

90 "President Cyril Ramaphosa: Additional coronavirus COVID-19 economic and social relief measures" (South African government media statement, 21 April 2020), available at: <https://www.gov.za/speeches/president-cyril-ramaphosa-additional-coronavirus-covid19-economic-and-social-relief> (last accessed 9 August 2021).

91 Ibid.

92 W Zembe-Mkabile, V Ramokolo and T Doherty "COVID-19 and social grants: Relief measures welcome, but not enough" (South African Medical Research Council), available at: <https://www.samrc.ac.za/news/covid-19-and-social-grants-relief-measures-welcome-notenough> (last accessed 13 July 2021).

93 J Bipat “COVID-19: WHO praises South Africa's 'community-based approach' to fighting the disease" (24 September 2020) The Herald. 
recommended several actions, some of which are consistent with those suggested by a number of organizations. Nevertheless, it acknowledged that the South African government did undertake some of the actions recommended through its policy response to the pandemic by, inter alia, providing social and economic relief measures to mitigate the impact of the pandemic on vulnerable people. That said, there is no doubt that there remains much room for improvement as it is estimated that the COVID-19 pandemic is going to continue for some time. Even after the approval and rollout of COVID-19 vaccines in early 2021, many countries, including South Africa, went on to experience second and third waves of the pandemic. Moreover, as mentioned above, COVID-19 is neither the first nor the last pandemic that the world will face. For these reasons, the scope for further research on the impact of the pandemic on vulnerable groups remains wide open.

\section{CONFLICTS OF INTEREST}

None 